\title{
O roli nauczyciela akademickiego $w$ opinii polskich i zagranicznych studentów
}

Streszczenie: Artykuł przybliża czytelnikowi wybrane aspekty obrazu nauczyciela akademickiego w deklaracji grupy studentów polskich i zagranicznych. W związku z zwiększającym się udziałem studentów z zagranicy w polskim rynku edukacyjnym autorka poszukiwała odpowiedzi na temat oczekiwań studentów związanych $\mathrm{z}$ rolą nauczyciela akademickiego. Celem artykułu jest przedstawienie wybranych aspektów roli nauczyciela w opinii studentów zagranicznych oraz polskich. Badanie opinii studentów zostało przeprowadzone w maju i czerwcu 2019 roku w Akademii WSB w Dąbrowie Górniczej, gdzie uczą się studenci z Polski, Ukrainy i wielu innych krajów świata. Autorka zakładała, że z powodu różnic kulturowych obraz nauczyciela akademickiego w oczach poszczególnych grup studentów może się różnić. Z przeprowadzonych badań wynika jednak, że studenci, co prawda, preferują różne formy zajęć, ale niezależnie od kraju, z którego pochodzą, oczekują aktywnego i energicznego nauczyciela, przekazującego wiedzę w sposób jasny i zrozumiały, będącego profesjonalistą w swojej pracy.

Słowa kluczowe: nauczyciel, student, aktywność, profesjonalizm, wykład, ćwiczenia

\section{Wprowadzenie}

Pedagogika międzykulturowa postrzegana jest współcześnie jako subdyscyplina pedagogiczna zajmująca się problemami edukacyjnymi społeczeństw zróżnicowanych kulturowo. Istotę problematyki badawczej tej gałęzi pedagogiki stanowi, zdaniem Przemysława Pawła Grzybowskiego, strukturalne podejście do analizy procesów edukacji na tle edukacyjnych zmian danego społeczeństwa. Fundamenty pedagogiki międzykulturowej są międzydyscyplinarne, dodatkowo wsparte antropologią, socjologią, historią, psychologią, językoznawstwem i innymi naukami (Grzybowski, 2011, s. 17).

Udział studentów z zagranicy na polskim rynku edukacyjnym wyraźnie wzrasta. Ta różnorodność kultur stawia polską edukację przed ciekawymi 
wyzwaniami. Zdaniem Jerzego Nikitorowicza zadaniem edukacji jest zaciekawić odmiennością, zrozumieć ją i traktować jako bodźcującą, wykazywać, że nie ma rzeczy obcej, która w pewnych warunkach nie mogłaby stać się swoją, a z drugiej strony każda rzecz swoja mogła być kiedyś obca (Nikitorowicz, 1996, s. 125).

Obecnie w polskim szkolnictwie wyższym wprowadzane są zmiany systemowe pod nazwą Nowa Konstytucja dla Nauki. Rząd postawił sobie za cel umiędzynarodowienie szkolnictwa, zintensyfikowanie współpracy nauki i biznesu, stworzenie nowych ścieżek kariery naukowej i dydaktycznej oraz dostosowanie liczby studentów na poszczególnych kierunkach studiów do realnych potrzeb rynku pracy. Efektem tych działań ma być znaczący wzrost pozycji polskiej nauki na arenie międzynarodowej. Internacjonalizacja sprzyja lepszemu zrozumieniu różnych kultur, służy rozwojowi uczelni, zmusza niejako do podnoszenia jakości kształcenia oraz stymulowaniu innowacyjności.

W roku akademickim 2017/2018 72,7 tys. cudzoziemców (w tym 37,2 tys. kobiet) planowało studiować w Polsce przynajmniej jeden rok akademicki. Większość cudzoziemców pochodziła z krajów europejskich, w tym ponad połowa (37,8 tys., czyli 52,0\%) z Ukrainy ${ }^{1}$. Ja pracuję w Akademii WSB, która od kilku lat stara się poszerzać swoją ofertę studiów dla obcokrajowców. Obecnie w Akademii w Dąbrowie Górniczej studiują studenci z niemal całego świata (m.in. z Indii, Albanii, Ekwadoru, Turcji, Tajlandii, Wietnamu), w tym największą grupę stanowią studenci z Ukrainy.

Do badań zainspirowały mnie nieformalne rozmowy ze studentami z Ukrainy, którzy zauważyli znaczną różnicę w podejściu oraz aktywności wykładowców podczas prowadzenia zajęć w Akademii WSB, w porównaniu ze szkołami i uczelniami ukraińskimi. Badania sondażowe przeprowadziłam w maju i czerwcu 2019 roku. Potwierdziły one założenie, że studenci niezależnie od pochodzenia i kultury oczekują, że wykładowca będzie aktywny i zaangażowany, a zajęcia przez niego prowadzone będą miały przełożenie na zastosowanie w praktyce.

\section{W poszukiwaniu efektywności}

Kompetencje merytoryczne, interpersonalne i dydaktyczne (Sajdak, 2007, s. 201) to rodzaje kompetencji, które Anna Sajdak wskazuje jako wiodące

1 Dane Głównego Urzędu Statystycznego, www.stat.gov.pl (dnia 21.06.2019). 
u nauczyciela akademickiego. Kompetencje te mają wpływ na to, czy studenci uznają wykładowcę za autorytet, specjalistę, a także czy zbuduje on na tyle dobre relacje interpersonalne, by można go było również nazwać skutecznym. Współcześni studenci wydają się bardzo wymagający wobec wykładowców, coraz trudniej zatem „zasłużyć” na miano autorytetu. Nawet dokonania naukowe wykładowcy nie są dla niego obroną, jeśli nie potrafi on przekazać wiedzy, lub też nie umie w wystarczającym stopniu zainteresować młodych ludzi wykładanym przedmiotem, by wzbudzić w nich potrzebę dalszego samodzielnego doczytania w danym obszarze wiedzy. W Polsce, podobnie jak na całym świecie, poszczególne branże zawodowe potrzebują młodych ludzi z gruntowną specjalistyczną wiedzą, kreatywnym podejściem do życia, a przede wszystkim otwartych na zmianę (Berłowski, 2018, s. 14). Oni to mają stanowić kapitał intelektualny, czyli źródło rozwoju gospodarek i społeczeństw na świecie. Zdaniem Billa Gatesa podstawą tego kapitału jest wiedza, do której zdobywania i przetwarzania powinno się przygotowywać młode pokolenia od najwcześniejszych lat. Tutaj wparcia, zdaniem Gatesa, potrzebują szczególnie nauczyciele. To oni, według amerykańskiego przedsiębiorcy, potrzebują doskonalenia i rozwoju, by móc przekazywać wiedzę w sposób interesujący i inspirować do zmiany².

Natalia Białek i Karolina Cyran piszą, że współczesny nauczyciel ma do czynienia z szybko zmieniającymi się potrzebami, które wymagają nowych kompetencji i działań w celu wspierania nowego podejścia do nauczania i uczenia się (Białek, Cyran, 2013, s. 141). Autorki sugerują, że w skuteczności uczenia dzisiaj pomocne są możliwości cyfrowych narzędzi. Edukacja musi, zdaniem Białek i Cyran, podążać w kierunku zindywidualizowania, a nauczyciel stać się aktywnym pasjonatem prowadzonych przez siebie przedmiotów. To droga niełatwa, zdaniem Karpińskiej-Musiał, wręcz wyboista, po której nauczyciele akademiccy zmierzają wciąż w kierunku profesjonalizacji działań i postaw, zgodnie z założeniem, że uczenie się jest procesem całożyciowym (Karpińska-Musiał, 2016, s. 15).

Pasja wykładowcy zdecydowanie objawia się w przekazie informacji. Jak mawiał Ludwik Hirszfeld: kto chce zapalać innych, sam musi płonąć3. Dla współczesnych studentów relacje z wykładowcą są naprawdę ważne, możli-

2 Wystąpienie Billa Gatesa na konferencji TED, Teachers need real , feedbackwww.youtube.com/watch?v=81Ub0SMxZQo\&t=2s (10 .06. 2019).

3 Ludwik Hirszfeld (1884-1954) - polski lekarz, mikrobiolog, immunolog i serolog. 
wość zadawania pytań w sytuacjach mniej formalnych, zmniejszony dystans, wzajemne zrozumienie. Współcześni studenci doceniają zaangażowanie dydaktyka i zauważają jego radość z nauczania innych. Sytuacja ta, w mojej opinii, nie zmieniała się na przestrzeni wieków, choć wydaje się, że relacje między wykładowcami a studentami obecnie nieco się rozluźniły ${ }^{4}$.

W czasie refleksji nad rolą współczesnego nauczyciela nasuwa się pytanie: czy są dzisiaj tacy wykładowcy, którzy dobro studenta stawiają na pierwszym miejscu, wzmacniają jego potencjał i budują bliskie relacje w trosce o jego wychowanie? Interesujące wydaje się także pytanie, czy dzisiaj są tacy studenci, którzy przyjdą tłumnie na nieobowiązkowy wykład i to znacznie wcześniej przed jego rozpoczęciem, by mieć jeszcze szansę na miejsce w sali? Czy w dobie Internetu i powszechności informacji młodzi ludzie ciągle potrzebują autorytetów i mistrzów na drodze swojego rozwoju? Jaki ma być współczesny wykładowca, by zainspirował do rozwoju, poszukiwania wiedzy? Moje badania sugerują, że ma być aktywny i energiczny, tak deklarowali studenci różnych narodowości. Słowo energiczny jest synonimem słowa aktywny, czynny, dynamiczny. Energiczny, jak ujęto w Słowniku PWN, może być człowiek i jego ruchy, jego energia to chęć i zdolność działania 5 . Aktywny i energiczny wykładowca to, zdaniem Natalii Białek i Karoliny Cyran, podstawa w procesie budowania nowego paradygmatu, który zakłada przejście od nauczania skupionego na aktywnościach profesora do nauczania skupionego na aktywności studenta. Konieczne staje się oparcie procesu nauczania na metodach aktywizujących, które ułatwią studentom dążenie do doskonałości (Białek i Cyran, 2013, s. 141). By spełnić te oczekiwania, może organizować prace w podgrupach, wymianę doświadczeń i aktywne uczenie się studentów od siebie nawzajem. Uczenie się wymaga interakcji wielu czynników: uczącego się, materiału, środka, za pomocą którego materiał jest prezentowany, sposobu zorganizowania prezentacji, osobowości nauczyciela, osobowości ucznia oraz środowiska, w którym zachodzi proces edukacyjny (Zimbardo, Johnson i McCann, 2017, s. 145).

4 W latach 2015-2017 prowadziłam badania dotyczące wybranych aspektów relacji między wykładowcami a studentami, którzy uczyli się metodą tutoringu akademickiego na Uniwersytecie Warszawskim. Analiza badań pokazała wyraźną korelację między kompetencjami komunikacyjnymi wykładowcy a częstotliwością wybierania go na tutora przez studentów. Wybierani byli ci wykładowcy, którzy byli mniej formalni w relacji i bardzo otwarci na współpracę.

5 Słownik PWN, https://sjp.pwn.pl/ (25.06.2019). 


\section{Nauczyciel akademicki - badania własne}

Badania metodą sondażu diagnostycznego (ankieta online) dokonałam na losowo wybranych studentach z grupy polskiej i międzynarodowej studiujących na kierunku Zarządzanie w Akademii WSB w Dąbrowie Górniczej. W badaniu wzięło udział łącznie 183 studentów. Sondaż odbył się na przełomie maja i czerwca 2019 roku. Przedział wiekowy studentów to 20-24 lata. W badaniu wzięło udział 40 studentów z Ukrainy, dlatego porównałam wyniki w trzech grupach:

- studenci z Polski N=98,

- studenci z Ukrainy $\mathrm{N}=40$,

- studenci z grupy międzynarodowej N=45 (Turcja, Kazachstan, Albania, Vietnam, Azerbejdżan, Tajlandia, Columbia, Tunezja.

Otrzymane wyniki badania pomogły mi określić następujące obszary:

- Którą formę zajęć, stosowanych w Akademii WSB, studenci deklarują jako najciekawszą?

- Jaki czynnik jest kluczowy, by zwiększyć zapamiętane treści podczas wykładu?

- Jaki czynnik jest kluczowy, by zwiększyć zapamiętane treści podczas ćwiczeń?

- Ocena wykładowcy - wskazanie jego cech osobowych.

Tabela 1. Forma zajęć preferowana przez studentów

\begin{tabular}{|l|c|c|c|}
\hline \multicolumn{1}{|c|}{ Forma zajęć } & $\begin{array}{c}\text { Studenci z Polski } \\
\mathrm{N}=98\end{array}$ & $\begin{array}{c}\text { Studenci z grupy } \\
\text { międzynarodowej } \\
\mathrm{N}=45\end{array}$ & $\begin{array}{c}\text { Studenci } \\
\text { z Ukrainy } \\
\text { N=40 }\end{array}$ \\
\hline Wykład & $16,3 \%$ & $15 \%$ & $\mathbf{4 8 , 6 \%}$ \\
\hline Ćwiczenia & $\mathbf{5 5 , 8 \%}$ & $30 \%$ & $25,7 \%$ \\
\hline Laboratorium & $19,8 \%$ & $12,5 \%$ & $2,9 \%$ \\
\hline Lektorat z języka obcego & $8,1 \%$ & $\mathbf{5 2 , 5 \%}$ & $22,9 \%$ \\
\hline
\end{tabular}

Źródło: badania własne.

Na podstawie danych zawartych w tabeli wnioskuję, że nie ma jednej ulubionej formy zajęć, którą preferują studenci. Mimo że odpowiadający są mniej więcej w tym samym wieku (od 20 do 24 lat), to Polacy najbardziej cenią ćwiczenia, studenci z Ukrainy wykład, a grupa międzynarodowa wskazała lektorat z języka obcego. Ta ostatnia jest dość skomplikowana w ocenie, bowiem studenci z grupy międzynarodowej uczęszczają na różne grupy językowe, w za- 
leżności od wyboru, najczęściej wybierają języki: niemiecki, francuski, polski, hiszpański. W pytaniu otwartym 26 studentów z grupy międzynarodowej tłumaczyło swój wybór lektoratu następującymi stwierdzeniami: to mniej nudne; lektorat jest bardziej dynamiczny; ważniejsze i bardziej interesujące; zajęcia językowe są przydatne, praktyczne, a nauczyciele naprawdę próbują uczyć; lektoraty są lepsze, masz więcej interakcji między małą grupą a profesorem.

Studenci polscy wybrali ćwiczenia, tak zdecydowała większość. Na lektorat z języka obcego wskazało zaledwie $8 \%$ badanych, to duża rozbieżność w stosunku do grupy międzynarodowej. Jednak powody, które zdecydowały o wyborze, wydają się zbieżne z opiniami grupy międzynarodowej. Polscy studenci $(\mathrm{N}=70)$, wybierając ćwiczenia, zdecydowanie wskazywali na takie walory jak praktyczność (aż 16 wskazań), ponadto: możliwość aktywności i zaangażowania się, energia, mniejsza grupa i łatwiejszy kontakt z wykładowcą, najlepiej przyswaja się informacje, większa różnorodność.

Wyniki studentów z Ukrainy zaskoczyły: choć ćwiczenia i lektorat uznają oni za ciekawe formy, to jednak niespełna połowa grupy jako formę najciekawszą wskazała wykład. Niestety swój wybór uzasadniło tylko 12 studentów, ale wypowiedzi koncentrowały się wokół stwierdzenia, że na wykładzie można usłyszeć więcej informacji, nauczyłem się wiele ciekawych rzeczy, wykłady są ciekawe.

W kolejnych dwóch pytaniach zachęcałam studentów do refleksji na temat czynników, które ułatwiają przyswajanie treści podczas wykładów oraz podczas ćwiczeń. Te dwie formy dominują bowiem w systemie kształcenia uczelni. Wskazałam wybrane czynniki, a student mógł wybrać do trzech odpowiedzi. W obu pytaniach zakładałam istotną rolę wykładowcy w przyswajaniu materiału. Dodatkowo w pytaniu otwartym zapytałam studentów o inne czynniki, które uznają jako pomocne w przyswajaniu treści z wykładów i ćwiczeń, a są im znane ze szkół w krajach, z których pochodzą.

Tabela 2. Czynniki ułatwiające zapamiętanie treści podczas wykładu

\begin{tabular}{|l|c|c|c|}
\hline \multicolumn{1}{|c|}{ Wskazany czynnik } & $\begin{array}{c}\text { Studenci polscy } \\
\text { N=91 }\end{array}$ & $\begin{array}{c}\text { Studenci ukraińscy } \\
\text { N=35 }\end{array}$ & $\begin{array}{c}\text { Studenci z grupy } \\
\text { międzynarodowej } \\
\text { N=41 }\end{array}$ \\
\hline Aktywny, energiczny wykładowca & $\mathbf{7 1 , 4 \%}$ & $\mathbf{6 0 \%}$ & $48 \%$ \\
\hline $\begin{array}{l}\text { Wykładowca dobrze zna język, w którym pro- } \\
\text { wadzi wykład }\end{array}$ & 0 & $22 \%$ & $\mathbf{6 3 , 4 \%}$ \\
\hline $\begin{array}{l}\text { Sposób mówienia wykładowcy (wyraźnie, gło- } \\
\text { śno, poprawnie) }\end{array}$ & $42,9 \%$ & $40 \%$ & $51,2 \%$ \\
\hline $\begin{array}{l}\text { Stosowanie środków audiowizualnych np. } \\
\text { prezentacja, filmy }\end{array}$ & $37,4 \%$ & $40 \%$ & $26,8 \%$ \\
\hline
\end{tabular}




\begin{tabular}{|l|r|r|c|}
\hline $\begin{array}{l}\text { Odpowiednio przygotowane slajdy, czytelne, } \\
\text { nieprzeładowane w treści }\end{array}$ & $45,1 \%$ & $34 \%$ & $29,3 \%$ \\
\hline $\begin{array}{l}\text { Przedstawianie najnowszych badań nauko- } \\
\text { wych, }\end{array}$ & $15,4 \%$ & $5,7 \%$ & $14,6 \%$ \\
\hline Podkreślanie najważniejszych treści & $31,9 \%$ & $40 \%$ & $43,9 \%$ \\
\hline $\begin{array}{l}\text { Możliwość dyskusji z wykładowcą podczas } \\
\text { wykładu }\end{array}$ & $45,1 \%$ & $54 \%$ & $48,8 \%$ \\
\hline Możliwość zadawania pytań, & $14,3 \%$ & $31,4 \%$ & $17,1 \%$ \\
\hline Sprawdzanie wiedzy np. przez testy pisemne & 0 & 0 & $4,9 \%$ \\
\hline
\end{tabular}

Źródło: badania własne.

Procentowo najwięcej odpowiedzi wśród studentów polskich uzyskało stwierdzenie: aktywny, energiczny wykładowca. To główny czynnik ułatwiający przyswajanie treści na wykładach. Podobnie najczęściej wskazywali tę odpowiedź studenci z Ukrainy. Ta odpowiedź nie była najczęściej wybierana przez studentów z pozostałych krajów. Grupa międzynarodowa wskazała jednak, że głównymi czynnikami ułatwiającymi przyswajanie treści podczas wykładu jest dobra znajomość języka ${ }^{6}$ oraz sposób mówienia wykładowcy (wyraźnie, głośno, poprawnie). Zakładam, że nie dość dobry poziom znajomości języka oraz niedostatecznie dobre brzmienie wypowiedzi wykładowcy wyraźnie utrudnia studentom zagranicznym przyswojenie treści z zajęć. Drugim czynnikiem najczęściej wybieranym wśród studentów polskich, ukraińskich i w grupie międzynarodowej jest możliwość dyskusji z wykładowcą podczas wykładu. Zakładam, że możliwość dialogu jest wartość cenioną w edukacji przez młodych ludzi na całym świecie. Konfrontowanie myśli zapewne sprzyja zrozumieniu treści, a także trwalszym ich przyswojeniu. Zaskoczył mnie fakt, że formy sprawdzania wiedzy, takie jak testy pisemne, nie są w opinii studentów czynnikiem, który powoduje przyswojenie treści z wykładu.

Interesujące są odpowiedzi, których udzielili studenci zagraniczni w pytaniu otwartym dotyczącym sposobów stosowanych przez wykładowców w krajach, z których pochodzą. W grupie międzynarodowej odpowiedziało 26 respondentów. Studenci wskazywali, że w ich krajach wykłady częściej bywają interaktywne, wykładowcy pytają na początku o informacje z poprzedniego wykładu, mówią niedługo, przerywają wypowiedzi pytaniami, korzystają z takich narzędzi jak filmy, utwory muzyczne, wyjścia poza uczelnię, a także konkursy i rankingi punktowane za aktywność na wykładzie. Studenci

6 Studenci wskazują na znajomość języka angielskiego, tylko w tym języku prowadzone są zajęcia dla grupy międzynarodowej w Akademii WSB, przy czym wykładowcy są pochodzenia polskiego. 
z Ukrainy ( $\mathrm{N}=14)$ wskazali skupianie się wykładowców na najważniejszych kwestiach wykładu, aktywowanie studentów poprzez pytania, pokazywanie przykładów, ciekawe prezentacje multimedialne i prace domowe.

Tabela 3. Czynniki ułatwiające zapamiętanie treści podczas ćwiczeń

\begin{tabular}{|l|l|l|l|}
\hline \multicolumn{1}{|c|}{ Czynnik } & \multicolumn{1}{|c|}{$\begin{array}{c}\text { Studenci polscy } \\
\mathrm{N}=91\end{array}$} & $\begin{array}{c}\text { Studenci } \\
\text { ukraińscy } \\
\mathrm{N}=32\end{array}$ & $\begin{array}{c}\text { Studenci z grupy } \\
\text { międzynarodowej } \\
\text { N=41 }\end{array}$ \\
\hline Aktywny, energiczny wykładowca & $49,5 \%$ & $46,9 \%$ & $58,5 \%$ \\
\hline $\begin{array}{l}\text { Stosowanie wiedzy z wykładu w praktyce (podczas } \\
\text { ćwiczenia, projektu, scenki) }\end{array}$ & $\mathbf{5 6 \%}$ & $37,5 \%$ & $\mathbf{6 8 , 3 \%}$ \\
\hline Praca w grupach i prezentacje wyników & $44 \%$ & $\mathbf{6 2 , 5 \%}$ & $41,5 \%$ \\
\hline Gry i zabawy & $19,2 \%$ & $34,4 \%$ & $14,6 \%$ \\
\hline Luźniejsza atmosfera (niż na wykładzie) & $49,5 \%$ & $18,8 \%$ & $9,8 \%$ \\
\hline Dyskusja podczas ćwiczeń & $42,9 \%$ & $37,5 \%$ & $53,7 \%$ \\
\hline Zadawanie pytań & $17,6 \%$ & $21,9 \%$ & $26,8 \%$ \\
\hline $\begin{array}{l}\text { Czynne przeżywanie informacji np. branie udziału } \\
\text { w scenkach, odgrywanie ról, wcielanie się w postacie }\end{array}$ & $24,2 \%$ & $46,9 \%$ & $26,8 \%$ \\
\hline Sprawdzanie wiedzy, np. przez testy pisemne & $2,2 \%$ & $3,1 \%$ & $7,3 \%$ \\
\hline
\end{tabular}

Źródło: badania własne.

Nieco inaczej kształtują się wyniki w przypadku refleksji badanych na temat ćwiczeń. W tym wypadku polscy studenci (56\%) oraz studenci z grupy międzynarodowej $(68,3 \%)$ wskazali, że czynnikiem, który sprzyja zapamiętywaniu treści podczas ćwiczeń, jest możliwość zastosowania wiedzy z wykładu w praktyce (podczas ćwiczenia, projektu, scenki). Dla studentów z Ukrainy najistotniejsze okazały się praca w podgrupach i prezentacje wyników (62,5\%). Na ćwiczeniach również ważny okazał się aktywny i energiczny wykładowca, a także dyskusja podczas ćwiczeń. Ciekawą jest odpowiedź dotycząca luźniejszej atmosfery na ćwiczeniach (w porównaniu z wykładami), ten fakt docenili głównie studenci polscy.

W powyższych odpowiedziach rola energicznego wykładowcy i aktywnych metod zajęć została dość mocno zaznaczona przez wszystkich studentów, respondentów badań. Wnioskuję, że od wykładowcy bardzo dużo zależy, jest on dla studentów ważny i ma znaczący wpływ na ocenianą przez studentów jakość kształcenia w uczelni. Dlatego kolejne pytania dotyczą postrzegania przez studentów wykładowcy. Zapytałam, jakie cechy osobowościowe powinien posiadać dobry wykładowca. W pierwszym pytaniu studenci wskazywali, czy nazwaliby znanych im wykładowców w Akademii WSB: przykładem, wzorem, autorytetem, mistrzem, profesjonalistą, urzędnikiem? W pytaniu tym można było zaznaczyć więcej niż jedną odpowiedź. 
Tabela 4. Cechy wykładowcy w opinii badanych studentów

\begin{tabular}{|l|c|c|c|}
\hline \multicolumn{1}{|c|}{ Wykładowca } & $\begin{array}{c}\text { Studenci polscy } \\
\mathrm{N}=91\end{array}$ & $\begin{array}{c}\text { Studenci ukraińscy } \\
\mathrm{N}=33\end{array}$ & $\begin{array}{c}\text { Studenci z grupy } \\
\text { międzynarodowej N=33 }\end{array}$ \\
\hline Przykładem & $38,5 \%$ & $48,5 \%$ & $45,5 \%$ \\
\hline Wzorem & $36,3 \%$ & $33,3 \%$ & $6,1 \%$ \\
\hline Autorytetem & $48,4 \%$ & $27,3 \%$ & $18,2 \%$ \\
\hline Mistrzem & $20,9 \%$ & $18,2 \%$ & $45,5 \%$ \\
\hline Profesjonalistą & $62,6 \%$ & $72,7 \%$ & $54,5 \%$ \\
\hline Urzędnikiem & $22,4 \%$ & $6,1 \%$ & $15,2 \%$ \\
\hline
\end{tabular}

Źródło: badania własne.

Wszystkie grupy wskazały najczęściej profesjonalistę jako określenie wykładowcy. Sporo osób z grupy polskiej wskazało także autorytet, z grupy ukraińskiej - przykład, a z grupy międzynarodowej także określenie - mistrz.

W kolejnym pytaniu poprosiłam respondentów o wskazanie, które z cech osobowościowych powinien posiadać dobry nauczyciel akademicki. W tym pytaniu można było zaznaczyć do 5 odpowiedzi. Kolejno wskazałam: sprawiedliwy, wyrozumiały, uczciwy, otwarty, opanowany, obiektywny, z poczuciem humoru, sumienny, komunikatywny, obowiązkowy, dobrze przygotowany do zajęć, pomocny, ambitny, szanujący godność człowieka, cierpliwy, szczery, wymagający, zaangażowany, rzeczowy, przyznający się do błędu, empatyczny, zdecydowany, życzliwy, przewidujący, stanowczy, konsekwentny, samokrytyczny. W tabeli została podana liczba osób, które wybrały daną odpowiedź.

Tabela 5. Cechy osobowe wykładowcy

\begin{tabular}{|c|c|c|c|}
\hline & $\begin{array}{c}\text { Studenci polscy } \\
N=90\end{array}$ & $\begin{array}{l}\text { Studenci ukraińscy } \\
\mathrm{N}=34\end{array}$ & $\begin{array}{c}\text { Studenci z grupy } \\
\text { międzynarodowej } \mathrm{N}=40\end{array}$ \\
\hline $\begin{array}{l}5 \text { najczęściej wskazy- } \\
\text { wanych odpowiedzi } \\
\text { w kolejności }\end{array}$ & $\begin{array}{l}\text { Poczucie humoru (54) } \\
\text { Wyrozumiały (45) } \\
\text { Komunikatywny (45) } \\
\text { Otwarty (44) } \\
\text { Dobrze przygotowany (38) }\end{array}$ & $\begin{array}{l}\text { Poczucie humoru (28) } \\
\text { Uczciwy (22) } \\
\text { Komunikatywny (20) } \\
\text { Sprawiedliwy (17) } \\
\text { Otwarty (17) }\end{array}$ & $\begin{array}{l}\text { Dobrze przygotowany (24) } \\
\text { Obiektywny (22) } \\
\text { Komunikatywny (21) } \\
\text { Pomocny (21) } \\
\text { Poczucie humoru (15) }\end{array}$ \\
\hline
\end{tabular}

Źródło: badania własne.

Poczucie humoru to cecha wskazywana najczęściej przez studentów polskich i ukraińskich, studenci z grupy międzynarodowej chcą współpracować z wykładowcą dobrze przygotowanym, czyli, jak zakładałam, profesjonalistą w wykonywaniu swojego zawodu. Cechą, która jest wspólna dla wszystkich grup respondentów, jest komunikatywność. 


\section{Podsumowanie}

Wykład jest formą organizacyjną procesu kształcenia, ale i metodą nauczania. Znani dydaktycy i twórcy typologii metod nauczania, Wincenty Okoń, Czesław Kupisiewicz, Kazimierz Sośnicki określali wykład jako jednokierunkowy przekaz informacji. Metoda ta pozornie wydaje się zatem prosta, jednak, jak pokazują przedstawione w artykule wyniki badań, metoda wykładu ewoluuje w formę zajęć znacznie bardziej aktywną, a od wykładowcy oczekuje się, że będzie on komunikatywny, aktywny, energiczny, wyraźnie zaangażowany, a także doskonale przygotowany merytorycznie. Istotne dla studentów zagranicznych jest, by nauczyciel biegle, poprawnie, wyraźnie i doniośle mówił w języku, w którym wykłada. Podobne oczekiwania względem nauczyciela mają studenci podczas ćwiczeń. Aktywny i energiczny wykładowca ma tak zbudować zajęcia, by umożliwić studentom zastosowanie wiedzy z wykładu w praktyce.

Nauczyciel w opinii studentów to profesjonalista. Według Stownika języka polskiego profesjonalista to ktoś, kto ma duże umiejętności w jakiejś dziedzinie i doskonale wykonuje swoją pracę ${ }^{7}$. Wnioskuję, że pod tym pojęciem mieści się także znakomite przygotowanie merytoryczne i metodyczne wykładowcy. Czesław Banach nazywa współczesnego nauczyciela profesjonalistą, który oprócz doskonałego przygotowania jest źródłem wiedzy, wartości etycznych oraz doświadczenia społecznego i etycznego. Taki nauczyciel wyzwala w studentach aktywność i wspomaga ich rozwój (Banach, 2004, s. 548). Sukces nauczyciela profesjonalisty zależy zatem od jego umiejętności radzenia sobie z różnymi zawiłościami i zmianami, które są obecne w polityce, gospodarce i kulturze, a także rozwiązywania praktycznych, codziennych problemów studentów, pochodzących często z odległych i różnych kultur.

Wyniki badania pokazują brak znaczących różnic w postrzeganiu form, metod i narzędzi dydaktycznych przez studentów polskich i zagranicznych. Beneficjentów łączą wysokie wymagania wobec wykładowcy, który ma być przede wszystkim profesjonalistą $\mathrm{w}$ swoim fachu, dobrze przygotowanym i na dodatek z poczuciem humoru. Interesującym dla autorki jest fakt, czy podobnie swoich mistrzów oceniliby żakowie na przestrzeni wieków. Wydaje się bowiem, że atmosfera na uczelniach w kraju i na świecie znacznie się rozluźniła, młodzi ludzie cenią wykładowcę akademickiego, ale nie postrzegają

\footnotetext{
7 https://sjp.pwn.pl (27.06.2019).
} 
go już jak mistrza czy niedościgniony wzór osobowy8. Współczesny nauczyciel jest, w opinii autorki, bardziej facylitatorem, coachem czy przewodnikiem w obszarze własnego rozwoju studenta. Cyfrowe pokolenie wychowane na multimediach, czyli obrazach i dźwiękach, oczekuje stymulacji, aktywności i dynamiczności na uczelni. To pokolenie wymagające, które autorytetów i wzorów osobowych szuka często na YouTubie czy Facebooku. Jeśli wykładowca „żyje” w tych równoległych światach, ma czynne konta na portalach społecznościowych, to, w opinii autorki, ma szansę być nazwanym pasjonatem swojego zawodu i być cenionym przez młodzież, z którą współpracuje.

Przedstawione badania nie aspirują do poszukiwań finalnych odpowiedzi na pytania zamknięte. Są głosem w dyskusji na temat kierunku, w którym podąża uczelnia polska i uczelnie zagraniczne, jako że proces internacjonalizacji rośnie w siłę, do Polski przyjeżdża coraz więcej chętnych do studiowania z całego świata. Obraz współczesnego wykładowcy akademickiego nie daje się zamknąć w ramy sztywnego opisu, a tym bardziej statystycznie zorientowanej metodologii. Wymyka się i będzie coraz bardziej wymykał procedurom, ponieważ zmiany społeczno-kulturowe narzucają nam życie w rzeczywistości mocno nieprzewidywalnej. Mam nadzieję, że niniejszy artykuł przyczyni się do prób ukonstytuowania bardzo ważnej i wymagającej roli nauczyciela akademickiego.

\section{Bibliografia}

Banach, Cz. 2004. Nauczyciel. W: Pilch, T. red. Encyklopedia pedagogiczna XXI wieku. T. 3. Warszawa: Żak, ss. 548-553.

Berłowski, P. 2018. Kluczem do udanej zmiany są ludzie. Personel $i$ Zarzadzanie. 10, ss. 13-17.

Białek, N. i Cyran, K. 2013. Aktywne metody dydaktyczne - subiektywne kompendium. W: Rozmus, A. red. Wyktadowca doskonaty. Warszawa: Oficyna Wolters Kluwer, ss. 141-145.

Brown, P., Roediger, H. i McDaniel, M. 2014. Harvardzki poradnik skutecznego uczenia się. Warszawa: Instytut Wydawniczy Pax.

Grzybowski, P. P. 2011. Edukacja międzykulturowa - przewodnik. Od tożsamości po język międzynarodowy. Kraków: Oficyna Wydawnicza „Impuls”. Grzybowski, P.P. 2012. Edukacja międzykulturowa - konteksty. Oficyna Wydawnicza „Impuls”.

8 To stwierdzenie jest osobistą refleksją autorki. 
Holmes, J. 2019. Edukacja i uczenie się. Warszawa: PWN.

Karpińska-Musiał, B. 2016. Edukacja spersonalizowana na uniwersytecie. Kraków: Wydawnictwo Libron.

Kędzierska, J. 2008. Profesjonalne kompetencje nauczyciela. W: Rudnicki, P., Kutrowska, B. i Nowak-Dziemianowicz, M. red. Nauczyciel misja czy zawód. Społeczne i profesjonale aspekty roli. Wrocław: Wydawnictwo Naukowe Dolnośląskiej Szkoły Wyższej.

Lewowicki, T., Ogrodzka-Mazur, E. i Szczurek-Boruta, A. 2008. Praca nauczyciela $w$ warunkach wielokulturowości - studia i doświadczenia z pogranicza polsko-czeskiego. Toruń: Wydawnictwo Adam Marszałek.

Lewowicki, T., Chojnacka-Synaszko, B. i Piechaczek-Ogierman, G. 2014. Edukacja dzieci i młodzieży w środowiskach zróżnicowanych kulturowo. Toruń: Wydawnictwo Adam Marszałek.

Robinson, K. 2015. Kreatywne szkoty. Kraków: Wydawnictwo Element.

Rozmus, A. 2018. Edukacja akademicka w perspektywie krytycznej. Kraków: Oficyna Wydawnicza „Impuls”.

Szempruch, J. 2012. Nauczyciel w warunkach zmiany społecznej i edukacyjnej. Kraków: Oficyna Wydawnicza „Impuls”.

Szempruch, J. 2013. Pedeutologia, Studium teoretyczno-pragmatyczne. Kraków: Oficyna Wydawnicza „Impuls”.

Okoń, W. 2012. Wprowadzenie do dydaktyki ogólnej. Warszawa: Wydawnictwo Akademickie „Żak”.

Zimbardo, P., Johnson, R. i Mc Cann, V. 2017. Psychologia, kluczowe koncepcje, motywacja i uczenie się. Warszawa: PWN.

\section{Netografia}

Słownik PWN, https://sjp.pwn.pl/ (25.06.2019).

https://sjp.pwn.pl (27.06.2019).

Bill Gates na konferencji TED, Teachers need real feedback, www.youtube. $\mathrm{com} /$ watch? $\mathrm{v}=81 \mathrm{Ub0SMxZQo \& t=2s}(10.06 .2019)$.

\section{The role of an academic teacher in the opinions of Polish and for- eign students}

Abstract: The article presents the selected aspects of the image of an academic teacher in the declarations of a group of Polish and foreign students. In connection with the growing share of foreign students in the Polish educational market, the 
author sought for the answers to the expectations of students related to the role of an academic teacher. The aim of the article is to present selected aspects of the teacher's role in the eyes of foreign and Polish students. The survey of students' opinions was carried out in May and June 2019 at the WSB Academy in Dąbrowa Górnicza, where students from Poland, Ukraine and many other countries were learning. The author assumed that due to cultural differences, the image of an academic teacher in the eyes of individual groups of students may differ. Although the research shows that students prefer different forms of classes, regardless of the country they come from, they still expect active and energetic teachers, who transform transferring knowledge in a clear and understandable way and are professionals in their work.

Keywords: teacher, student, activity, professionalism, lecture, classes

Translated by Edyta Nowak-Żółty 